\title{
土石流に関する最近の研究
}

\author{
奥 田 節 夫* \\ Recent Studies on Debris Flow in Japan
}

Setsuo OKUdA

\section{I. 土石流研究の意義}

「土石流」という言葉は, 学術的にも俗語的にも広く用いられるが，学術的に限ってみても，土・石・ 水が混じり合って集合的運搬態をとって流動する「物理的現象」とする場合と, 主として谷底に堆積して いた大量の土石が, 水の供給を受けて急激に流動を開始し, 高速で長距離にわたって流下する「地学的現 象」とする場合とで，ある程度とり扱いが異なってくる。

本稿では主として「地学的現象」としての「土石流」について，防災科学の立場から最近の研究の状沉 を紹介するが，「物理学的現象」としての究明過程もそのなかに部分的に含まれている。

まず防災科学の立場から，「土石流」の人命に対する直接的脅威について述べる。国土庁編防災白書1986 年版の，1967 1984 年の自然災害による 死者・行方不明者の原因別状況の推移によると, 犠牲者の数が 400名を越える大災害のあった年には，土石流・山くずれなどの土砂災害によるものの割合が $60 \%$ 以上に も達することがうかがえる。このらちでとくに土石流によるものの割合は, 被災現地でみた土石流の分類 の仕方によって多少変わってくるが, 従来の建設省のデータやわれわれの被㷋地での調査経験からみて, 過半数にのぼるものと考えられる。

このように土石流が直接的に土石埋没の犠牲者を数多くもたらす理由としては, 一つには洪水の発生に くらべて, 土石流発生の時期・場所・規模の予測が難しいこと, また現象の発生は山奥で, 被害の発生は 谷の出口で起こり, 直接に現象発生を確認してから避難するのが難しいことなどの理由で, 全く不意打ち 状態で襲われる場合がきわめて多いためであるう。したがって, 土石流の発生の予測と, 土石の流動形 態, その到達・堆積範囲の定量的研究は, 災害の防止のためにきわめて緊急な課題といえよう。

また地学的現象としての「土石流」研究では, 土石流の発生・流動と谷および扇状地の地形変化との相 互関連性を究明することは, 地形学分野での興味ある課題となるであるう。土石流が谷の侵食と扇状地の 発達をもたらすことはよく知られているが，逆に谷への土石の供給や扇状地の微地形変化は，土石流の発 生・流動・堆積の過程を大きく支配している。

さらに物理学的現象としての「土石流」は, 直径数ミクロンの粘土粒子から数メートルの岩塊までのさ まざまな粒子群と水の混じりあった典型的な混相流（Multi-Phase Flow）として, 流体物理学の興味深い 研究対象となっている。その流動体の研究の成果は, 土石流の被害防止のみでなく, スラリー輸送などの 他の技術分野でも利用されるであろう。

以上「土石流」現象の学術的研究は, 単に防災科学分野での要求に応じるのみでなく, 地形学・流体物 理学分野においても有用な成果をもたらすものと考えられる。

* 京都大学防災研究所 Disaster Prevention Research Institute, Kyoto University 


\section{II. 土石流の現地計測}

地学現象の研究は，まず自然現象そのものを忠実に観察することから始まるが，「土石流」についても例 外ではなく，京都大学防㷋研究所の「土石流研究グループ」は，まず現地で土石流の動態を観測する手法 の開発から始めた。われわれの観測手法開発以前（1970年以前）にも，現場の砂防工事関係者が土石流の

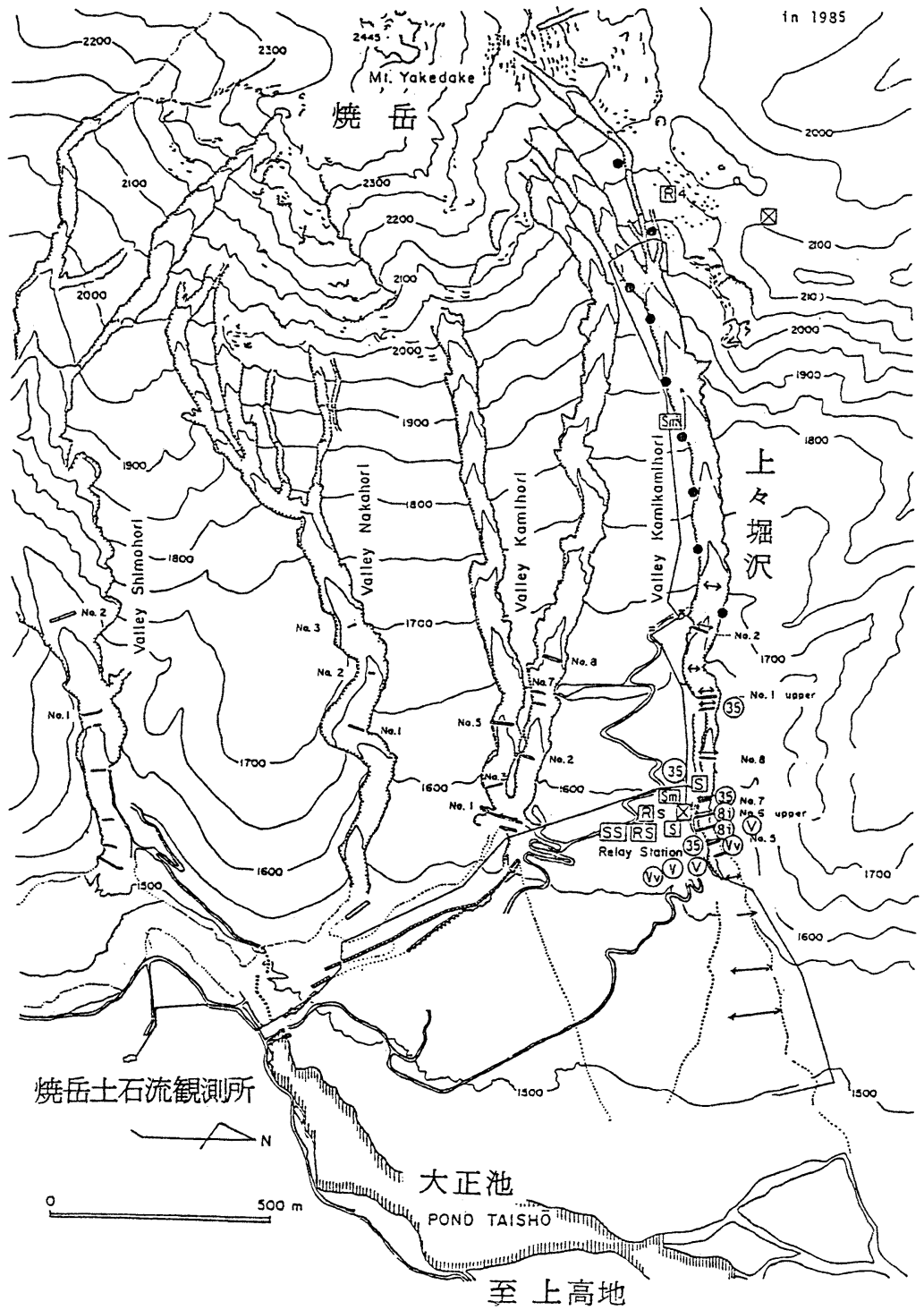

第 1 図 調查地点と観測機器の配置 (1985)

区：中継所，目：雨量計，↔：ワイヤーセンサ, $\mathrm{SS}$ : 空間フィルタ流速計, $\mathrm{RS}:$ 電磁波ドッ プラー流速計， $\mathrm{S}$ : 振動計， Sm: 振動モニター, (35：35ミリモータドライブカメラ，(8)、

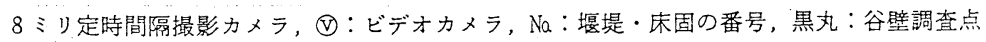


動態をスチルカメラやシネカメラで撮影記録した貴重な記録例はあるが，その殆どは偶然のチャンスに撮 影されたもので，定量的な解析に利用することは難しい状態であった。

このような実状にかんがみ，われわれは，「身の危険を冒すことなく，偶然に頼らないで，計画的に確実 に土石流の動態を記録すること」を目標にして, 土石流の遠隔自動計測システムの開発に努的てきた。最 近では, われわれのグループの他にも, 建設省や大学によって, それぞれの地域・目的に応じた土石流の 現地計測が実施されつつあるが，本稿では，われわれが建設省松本砂防工事事務所と協力して焼岳の東斜 面の上々堀沢に現在設置している計測システムと，それによって得られた成果の概要について説明する。

1) 計測システムの概要

1985年夏の焼岳東斜面上々堀沢における土石流計測の対象フィールドと各種計測機器類の配置を, 第 1 図に示し，観測システムの総合的な構成を第 2 図に示した。各種のセンサ類は谷に沿ってセットされてい るが，レコーダ類は中継所及び観測センターに集められている。各種のセンサやそのデータの記録方式等 (SUWA and OKUDA 1986) については, 主要なものに限ってごく簡単な説明をするにとどめる。

(i) 流速測定

ワイヤーセンサは, 電線を谷の横断方向に張ったもので, 土石流の先端がここに到達してこれを切断す ると, 切断時刻が秒の精度で観測センター内のプリンタに印字記録されるようになっており, 隣接センサ の切断時刻の差から両センサ間の土石流の平均速度が求められる。同時にこのワイヤーセンサは, 上流に 㧍ける土石流発生を確認し，下流での各種の計測機器（例えばビデオカメラ等）に制御信号を送る役割も 果たしている。

ワイヤーセンサとは独立に, 土石流の表面流速を測るために, 電磁波ドップラー流速計と空間フィルタ 一流速計とがセットされている。土石流に対しては, 通常の流速計のような機器は岩塊の衝撃によってた ちまち破壞される抢それがあり，今のところ上述のような非接触型のセンサによる表面測流に限られてい る。

(ii) 映像記録

土石流の動態の定量的な解析に，きわめて有効に利用できるのは映像記録である。そのために，第 1 図 に示寸ように，多数の 35 ミリモータードライブカメラ・8ミリ定時間隔撮影カメラ・ビデオカメラが谷沿 いにセットされている。これらの映像記録の主目的は, 土石流の流動速度・流動形状 (断面積の形・大き

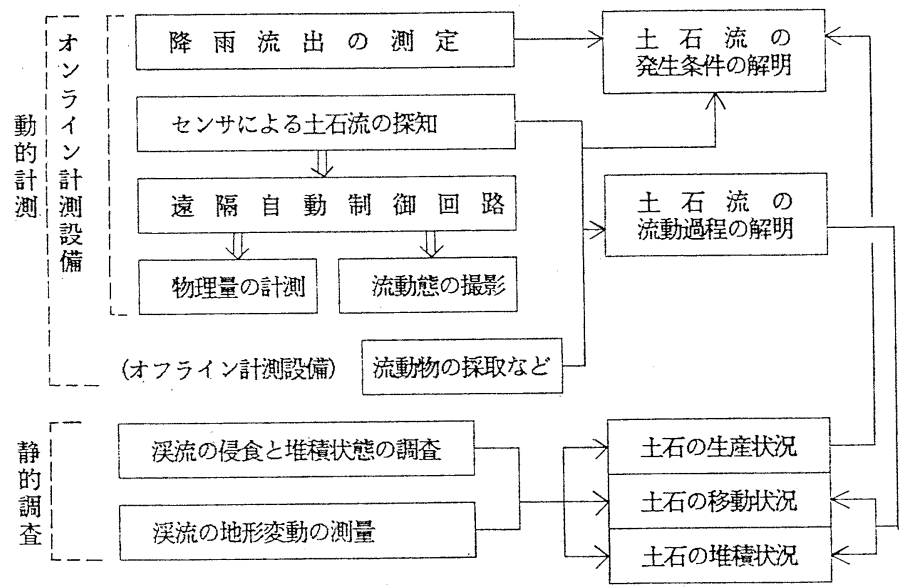

第 2 図土石流の総合的な現地計測の構成。 さなど)・流動物組成の連続 的なデータの取得である。

(iii) 地盤振動

土石流が谷沿いに流下寸る とき地盤に大きな振動をもた らすことは，経験的によく認 められて抢り，下流の住民が 上流での土石流発生を足下に 伝わる振動から察知した例む ある。そこで, 土石流の流下 にともなう地盤の振動を測定 することによって 上流にお ける土石流の発生を早期に知 り，また，振動の記録（振 幅 - 周期)から土石流の規模, 
接近の速さを求め, さらには谷岸での振動による被害の有無を検討するために, 簡単な振動センサと 3 成 分地震計による振動測定が行われている。

(iv) 雨量

上述の計測システムのほかに，土石流発生の水文学的条件を直接に支配する雨量の観測が，対象流域の 上・中・下流の 3 地点で行われている。その記録は観測センターに集められ，刻々の雨量が分かり，土石 流発生の近づいた状態では各種の測定機器が手動でも操作できるようになっている。

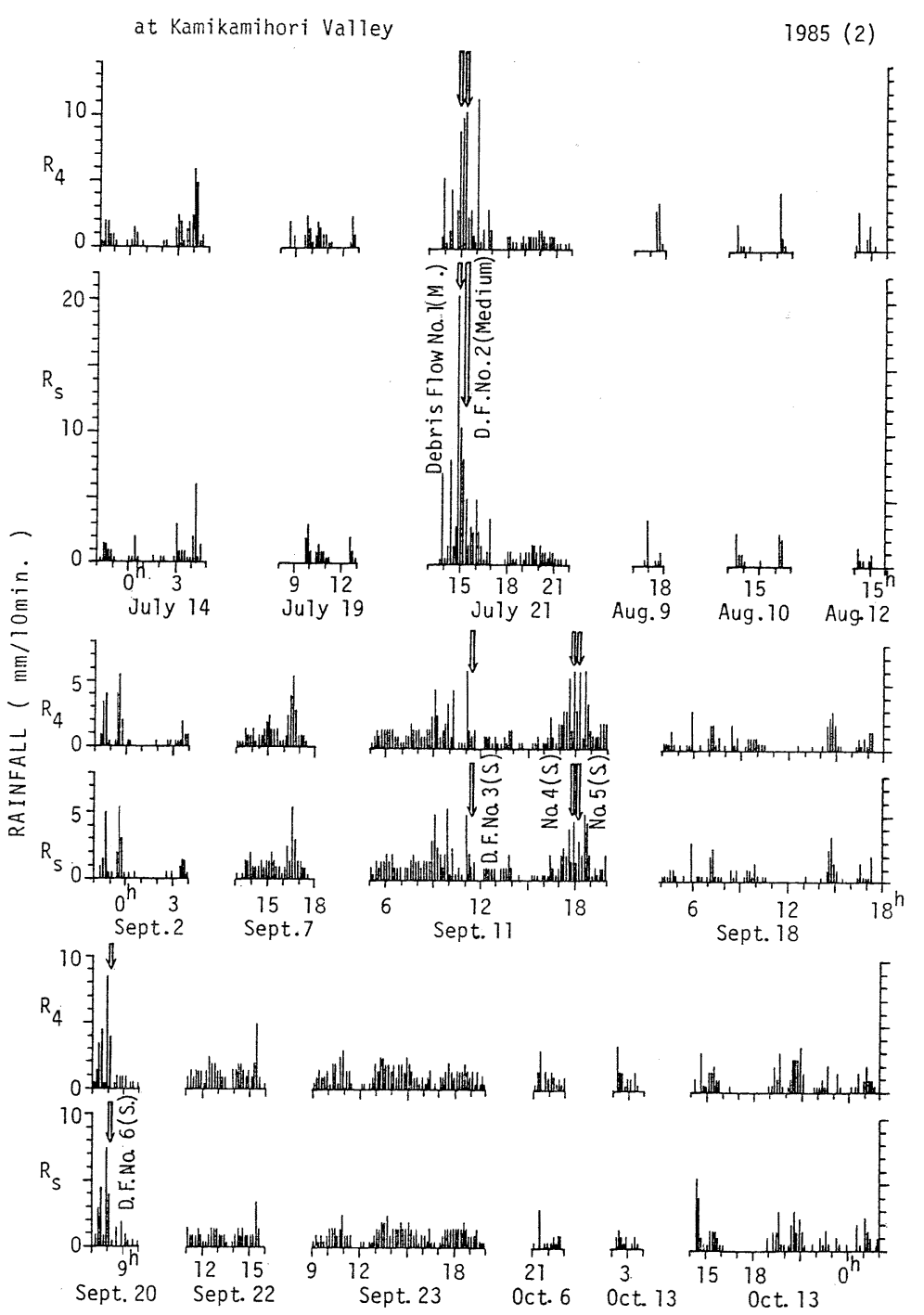

第 3 図 10 分間雨量と土石流の発生時刻 (矢印で図示)。測定点 $R_{4}$ は燒岳上々堀沢の 源流域のもので, Rs は同じ沢の下流域のもの(約 $1500 \mathrm{~m}$ だけ離れている). M. は土石流の規模が中規模であることを，S．は小規模であることを示す． 
2) 現地計測の成果

以上述べたような計測システムによって，焼岳東斜面において，すでに10年以上にわたって計測が行わ れてきた。その結果, 土石流の発生・流動態について多くの新たな知見が得られている。その具体的内容 についてはすでに詳しく報告されているので（京大防災研年報14 29号 1971 1986, 松本砂防技術資料 No. 5 19，1975 1986), 本稿では主要な項目について簡単に紹介する。

(i) 降雨と土石流発生の関倸

山くずれなどをふくめて，一般に斜面の崩壊の発生が，先行降雨と降雨強度に大きく支配されることは よく知られているが，第 3 図に示すように，焼岳東斜面においては，とくに10分間雨量のピークが土石流
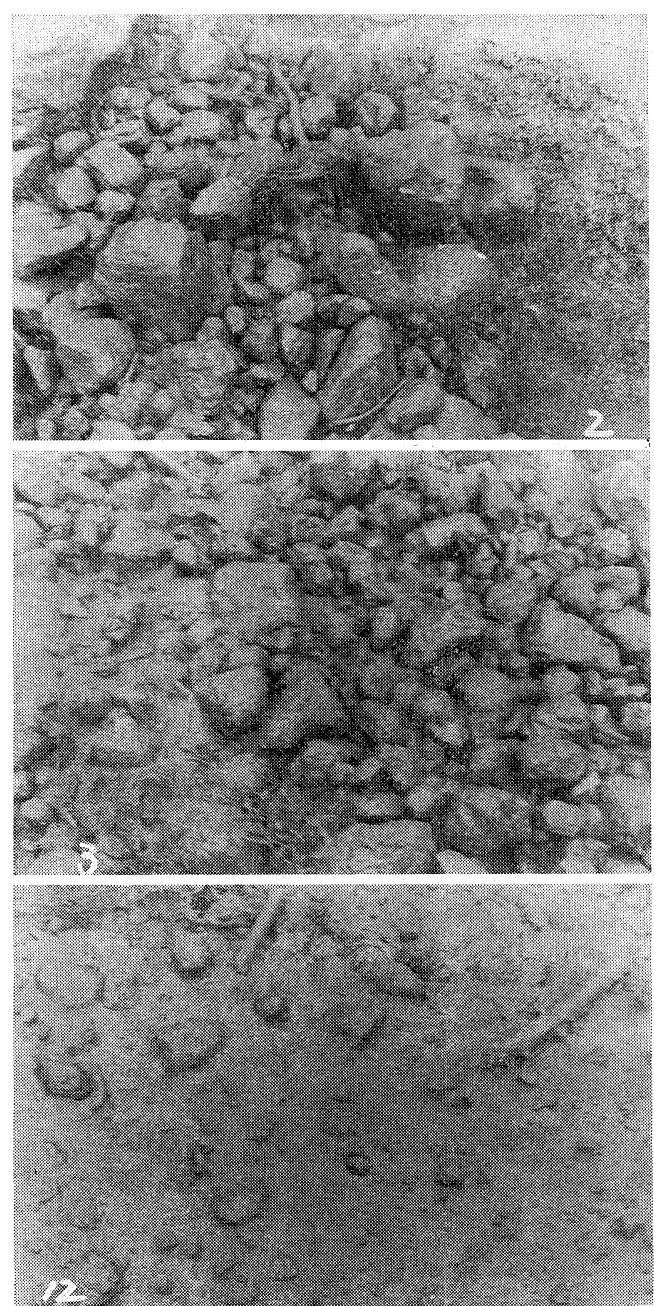

写真 1 1985年 7 月 21 日に焼岳上々堀沢に発生 した土石流の第 1 波の俯瞰写真. 土石 流は縦 $4.7 \mathrm{~m}$ 横 $6.6 \mathrm{~m}$ の視野を右向に 流動. 写真の中の数字は土石流先端が 視野内に入り始めた瞬間からの経過時 間（秒）を示す.
発生によく対応する。この現象は集水面積 $1 \mathrm{~km}^{2}$ 程 度の谷では共通の傾向と思われるが, 先行降雨と降 雨強度の組み合わせのみで，土石流の発生・非発生 を正確に判断することはなかなか難しい。というの は, 大きな土石流が発生して, 谷底に溜まっていた 土石がほとんど一掃され, 岩盤が露出する状態で は，豪雨が降っても土石流が発生し難い，という例 からも想像できるように，降雨のみでなく，谷底の 土石の堆積状態が土石流の発生を大きく支配するか らである。なお最近は, 土石流発生の水文的条件を さらに詳しく調べるために, 源流域における地下水 分布の変化や表面流量の観測, Kinematic Wave 法 による流量推定などが行われている。

(ii) 土石流の流下速度

一般に土石流は, 発生直後から急勾配の谷にそっ て加速流下し, ある平衡速度に近づいたのち, 下流 の緩勾配部にさしかかって減速し，ついには停止す る。われわれの計測システムによる土石流の先頭部 の運動は速度の変化の実測例も, 大体この傾向を示 しており，中流で $2.5 \sim 8 \mathrm{~m} / \mathrm{sec}$ 程度の 速度が測ら れている。実測によれば, 同じ谷でも土石の量の大き ものほど高速で長距離にわたって流下している。谷 の勾配, 土石流の組成・規模から流速を求める一般 的な流速表現式は，未だ確立されていない。

(iii） 先頭部のハイドログラフ

土石流の流動形態の大きな特徵は, 先頭部に大岩 塊が集まって高い盛り上がりをもつことであり，そ のために大きな運動量がこの部分に集中し，土石流 の被害を大きくする原因となっている。その状況を 定量的に確かめるため, とくに先頭部の流速, 盛り 上がり形状, 岩塊群の分布を測定するように, 計測 システムに特別な工夫が払われている。写真 1 は駒 撮りカメラによる先頭部の岩塊群の集中状況の記録 であり，第 4 図は先頭部から後続部への流動態の遷 


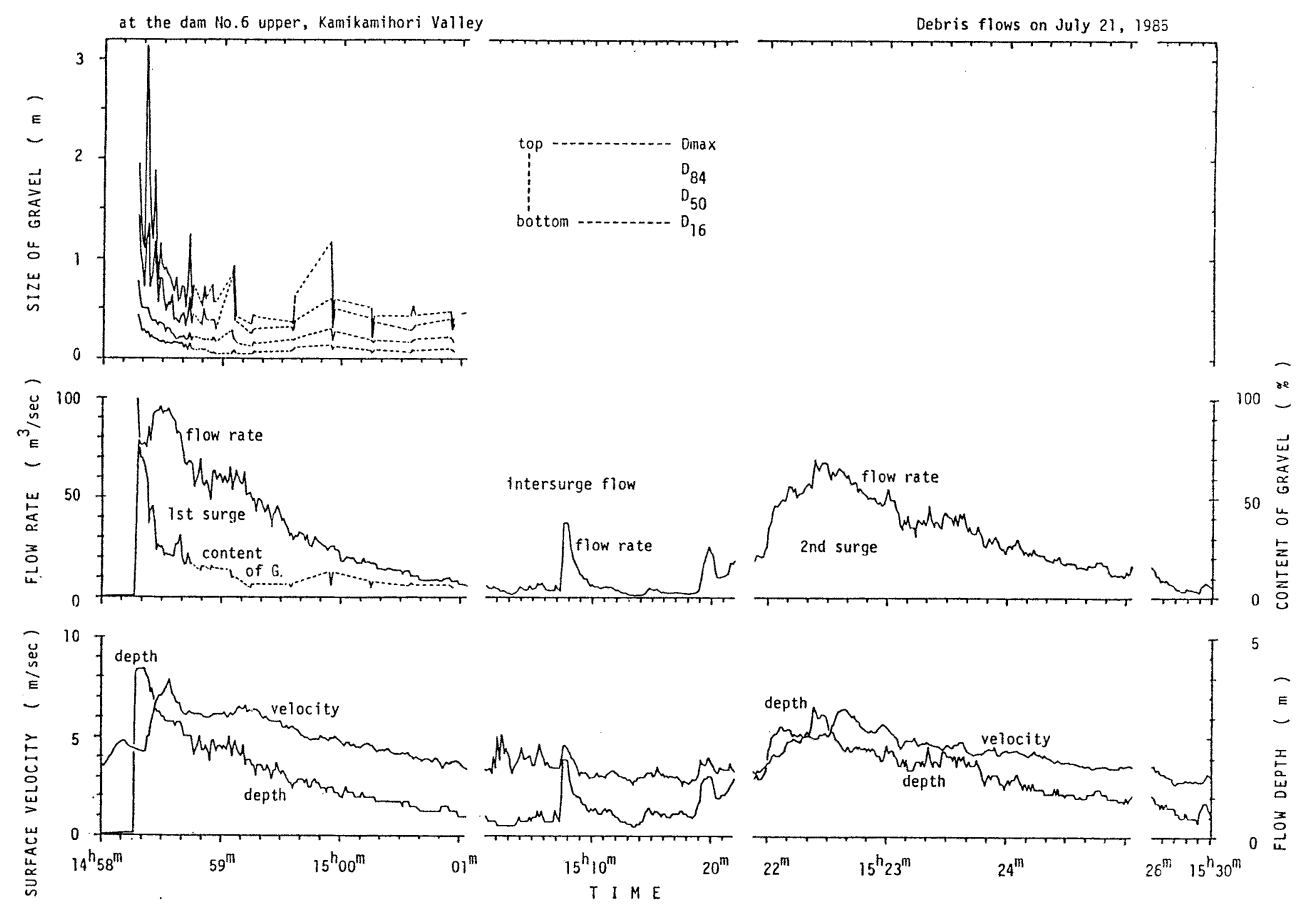

第 4 図 1985年 7 月 21 日に発生した土石流の八イドログラフと，粒径 $10 \mathrm{~cm}$ 以上の石磪 の濃度曲線および粒度特性值曲線

移を示すハイドログラフである。これによって，土石流の先頭部には大きな岩塊が集まって盛り上がって おり，後方になるほど粒子が小さく，厚みも小さくなって，土砂流・泥流に近い形態になってゆくことが 認められる。

(iv) 振動

土石流が通過する際の渓岸の地盤の振動の記録をみると，先頭部では強くて長周期の振動が，後続部で は弱くて短周期の振動が生じており，これらの記録から土石流の流動方向の構成物の変化をうかがうこと ができる。

(v) その他

直接計測システムによる計測成果ではないが，特殊な採取装置によって土石流から流動物（砂礫以下の 細粒）の採取が行われ，その分析によって，土石流のバルク密度 $\left(1.5 \sim 2.0 \mathrm{gr} / \mathrm{cm}^{3}\right)$ や粒径分布が調べら れている。また砂防ダム袖部にとりつけた圧痕計によって, 大岩塊の一回の衝突で数トン重の衝撃力が生 じることが測られている。

\section{III. 土石流の発生・流動と地形変化の相互関連性}

土石流の発生・流動は谷および谷の出口の扇状地に顕著な地形変化をもたらすが，逆にまた谷の中での 土石収支や扇状地の微地形変化は，土石流の発生・流動・堆積の諸過程に大きは影響を及ぼす。とくに焼 岳東斜面の谷のように最近（1962年）の噴火後士石流が頻発しているところでは，10年くらいの閒にきわ めて顕著な地形変化が現れてくるので，その変化の追跡は，火山体の開析とそれにともなら扇状地の発達 の地形学的研究に, きわめて有用なデータを供給するものである。われわれは毎年数回, 谷の縦・横断形 
状と扇頂の堆積域について定期的な地形測量を行い, さらに土石流発生前後の地形変化を調べるための特 別測量や，特定の谷壁の季節的な微地形変化を追跡するための写真撮影などを，くり返し行なっている。 その成果についてもすでに論文として発表しているので，(OKUDA et al. 1980）ここでは簡単な紹介に とどめる。

空中写真の比較や測量によると, 上々堀沢上流の急崖部では 15 年間に $30 \mathrm{~m}$ に近い谷底の低下が生じてお り，また下流の大正池は 16 年間に湛水面積がほぼ半分近くに縮小しているが，これらの事実は，土石流に よる土石運搬量の大きさを物語っている。

いっぽう，谷壁から谷底への主として落石形態での土石の供給は，春先の凍結・融解のくり返し時期 と, 梅雨期・台風時の表流水によるものが多く, 谷壁の形状による土石供給量の差から, 谷の縦断形にス テップ状の形が現れてくる。谷底に堆積した土石は, 夏から秋にかけての豪雨時に発生する土石流によっ て大量に運び出され，ステップ状の縦断形は平滑化されてくることが多い。このように谷の形状は，横 方向からの土石の供給と縦方向への土石の流出のくり返しによって, ある程度季節的な変動をくり返し ているが，長年の間には，大規模土石流による土石の搬出があり，平均的には谷底の低下が進行している (SUWA and OKUDA 1987)。

谷の出口の扇状地の堆積については, 土石流が扇状地に到達するたびに, 新しい堆積域の測量を行って いる。その結果によると, 堆積形態には，土石流先頭部が盛り上がったままで停止したような「盛り上が り型」と，かなり搪がって薄くなって停止した「平坦型」とが見出されたが，第 5 図に示すように，扇央 より上流に停止したものは前者の形態であり, 扇央から扇端にかけて停止堆積したものは後者のタイプで ある。しかし，流動形態および流動物組成とこの堆積形態との関連については，未だ明らかでない。

一つ一つの土石流は, 扇状地に到達してもあまり側方には拡がらないで, 細長い lobe を造り, そのあ とから到達した土石流は, 扇頂付近の微地形変化に応じて大きく流れの方向を変えて流下し, 第 5 図に示 すように，指を開いたような分布で堆積域が形成されてゆく。そして長年の間には，等確率的にさまざま な方向に堆積してゆくから，結果的には同心円状の等高線をもった扇状地が 発達してくる（奥田・諏訪 1984)。

このように, 满状の扇頂流路の変化が下流での土石流の堆積域を大きく支配することは, 堆積域の予測 を困難汇するものであるが，いっぽう，僅かな人為的地形改変によって土石流堆積域を制御できる可能性 を示すものとも考えられよう。

\section{IV. 土石流現象の理論的 - 実験的研究}

以上主として地学現象としての「土石流」の実態を把握するための現地計測手法による観測と, 土石流 と地形変化の相互関連性を調べるための現地測量の成果にもとづいたわれわれの研究を紹介した。

しかし土石流の発生の予測, 流動・堆積の諸過程の究明のためには, 水理学また土質力学の観点から理 論的あるいは実験的な究明が必要なことは云うまでもない。

つぎに土石流の発生・流動・停止の諸過程別に，最近行われてきた理論的・実験的研究の概要を紹介寸 る。

1) 土石流の発生過程

土石流の発生の理論的考察は, 従来の無限長直線斜面の安定性の検討と本質的に異なるところはない。 ただし，とくに土石流の場合に問題となるのは，堆積層の上面の表流水の影響や，崩壊が始まったのち に，単に崩れるだけでなく，堆積粒子が水をふくんで流れやすくなるといら抵抗力の減少過程の説明であ る。また，堆積物の表層近くの粒子のみが掃流されても土石流の発生にはならない。高橋（1983）はこの ような条件を考慮して, 土石流の発生とその直後の先頭盛り上がり部の形成について，理論的考察にもと ゔく解析式を導いている。 


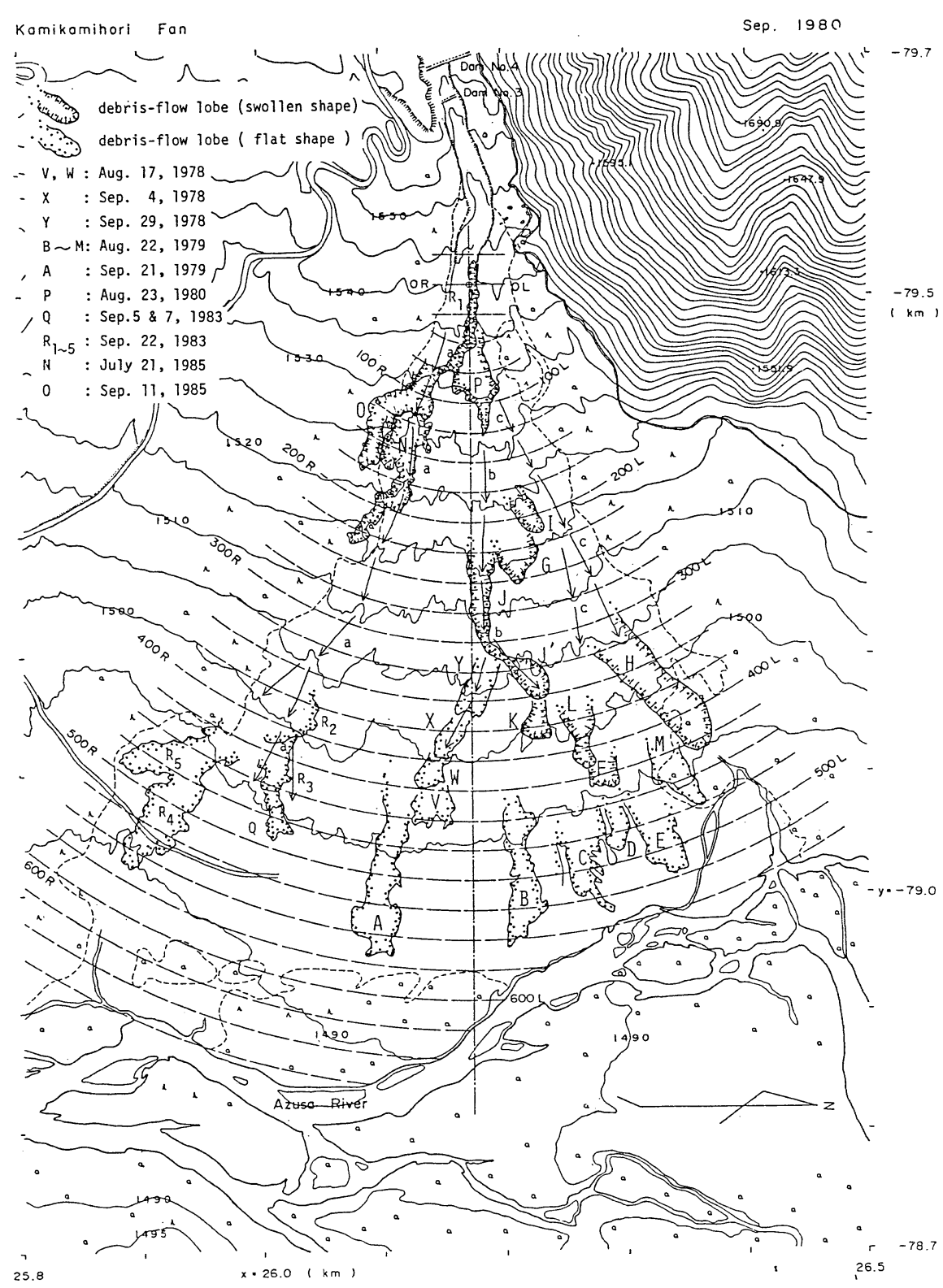

第 5 図上々堀沢扇状地に形成された土石流堆の分布（1977〜1985 年). 土石流の流走 径路は1970～71年には矢印 a の，1972～75年にはb と c の，1976〜 78年には b の，1979年にはbとcの，1983〜85年にはaの方向へと推移してきている.

また堆積物の底層での閒隙水圧の急激な上昇について，佐々ほか（1985）は，谷底の間隙の大きい堆積 層に外的な荷重（谷壁からの土石崩落や上流からの土石流下など）が加わって間隙が圧縮する場合を想定 し, 地震時の地盤液化現象に類似のメカニズムで流動が始まる可能性を指摘している。 
このような考察は土石流発生過程の基礎的な モデルとして有用であるが，実際の谷の源流域での降雨 (西るいは融雪) による水の地面への供給データを用いて土石流発生の時期・場所・規模を予測するために は，さらに流域や谷底の地形的また水文学的な諸パラメータの情報が必要である。

\section{2) 土石流の流動機構}

従来の土石流の流動機構の説明には, 水と固体粒子の混合物質を一つの均質な物質とみなして, そのレ オロジー特性から流動の法則性を導こうとする立場と，水と粒子を区別し，粒子相互の衝突による応力と 水の分子粘性・乱流粘性による応力とをくらべ，一方のみあるいは両方を考慮して，流動の法則性を求め ようとする立場とがあった。前者は，とくに細粒分の多い濃い泥流などの場合に，ビンガム流体としてと り扱うことによって，その流動性を説明することができるが，わが国の多くの溪流に発生する粘土分が少 なく砂砂成分の多い土石流には，適用できない。

後者の代表的な考え方は，BAGNOLD（1954）によって半ば実験的に導かれたもので，速度のシヤーを もつ流れの中で，粒子の相互衝突・反発で生じる応力によって粒子間の空間が保持され，低抵抗の流動が 続けられることを示した。高橋（1983）はその考えにもとづいて粒子群の開水路での定常流の流速分布を 導き，水理実験によって，このモデルが他の流体モデルよりも良く実測分布に適合することを示した。

なお BAGNOLD の粒子流の考えは，単にその流速分布の説明だけでなく，大きさの異なる粒子が混在 する場合に，流速の分布による上下方向の衝突回数の差によって大きな粒子が相対的に浮かび上がってく る—いわゆる逆級化 (inverse grading) 現象の説明を可能にしている。これらの詳細については, 高橋 保のレビュー（高橋 1984）によくまとめられている。

この逆級化現象によって大きな岩塊が表層に浮かび上がると, 表層は下層に比べて流速が大きいために 流れの前方に運ばれることになり，先頭に大きな岩塊が集中するという観測事実が説明される。ただし逆 級化の原因は，BAGNOLD の示した粒子間衝突応力のみでなく他にも存在するので（諏訪ほか 1984 , 1986), 実際の土石流についてはさらに実験や実測による検討が必要である。このような理論的あるいは実 験的な解析は，土石流の流動機構の解明に非常に有効であるが，その前提条件がかなり単純化されている (例えば粒径一定等) ために，現場での適用には困難な面も少なくない。

谷沿いの土石流の運動状態を上流から下流まで追跡するためには，土石流の主要部（とくに先頭部）を 一つの物質塊とみなして，これの斜面沿いの運動を質点力学的に解析することが実際的で簡明な手法であ るが（例えば奥田 1986）, この場合には，物質塊と斜面の間の動摩擦係数と，運動にともなう流体抵抗を きめる抵抗係数を, 具体的に求める必要がある。これらの係数は, 現地での土石流の流速変化の計測結果 から求められるが，流動物の運動の状態から実験的に求めることも試みられている（芦田ほか 1985）。こ の問題については，さらにさまざまな土石流に対する現地計測值と実験室等で求めた見積值との比較が必 要であろう。

\section{3) 土石流の堆積機構}

土石流の減速・停止についての考察には, 流動に関する解析結果が適用できる面もあるが, 独立して配慮 すべき問題も多い。急勾配の谷から緩勾配の扇状地に流れ出た土石流の停止過程については，高橋 (1983) の解析がある。しかし実際に扇状地での土石流の停止・堆積の過程を究明するためには, 谷の中での運動 の場合と異なり，側方への土石の拡がりと，土石流の先頭部と後続部の分離の現象の考察が必要である。

扇状地が一様な平面であれば，側方への拡がりもある程度単純な理論的解析が可能であろうが， 3.で述 ベたように，自然の扇状地では，過去の土石流堆積による異方性をもった微起伏（前述の指を拡げたよう なパターン）の存在を無視することはできない。土石流がどの方向に進むかはそのときの扇頂付近の微地 形によって決定され, どれかの溝状低地に沿って流下する。そして多くの場合, 土石流の先頭 部が減速 
し, かつ多少拡がって薄くなり始めると, 後続の土砂流あるいは泥流状の流れは先頭部と分離して, 先頭 部をのりこえたり，先頭部の側方をすりぬけたりして，先に流下する。

このように, 土石流先頭部は扇状地に到達すると変形・変質しながら減速・停止するから, その過程の理 論的解析は谷の中での開水路状の流れにくらべて格段に難しくなる。しかも防災科学的見地からすると, 谷 を出てからの土石流の停止，土石の拡散範囲の予測がもっとも重要な課題である。そこでこの問題につい ては, とくに模型水理実験による研究, 現地観測による経験的法則性の探究, あるいはランダムウォークモ デルをとり入れた確率論的推測などが試みられているが，総合的な結論は導かれていない（武居 1984）。

\section{V. 土石流研究成果の防災対策への活用}

土石流の研究成果が実際の防災に役立つためには，学問・技術・行政の連携が必要であるが，いまのと ころ次の二方向での研究成果の現実的利用が考えられる。一つは土石流の発生を予測して適切な避難を可 能にすることであり，もう一つは土石流そのものを制御する方法を工夫することである。

前者については, IV-1)でも論じたように, 土石流の発生機構が原理的に解明されても, 降雨の情報から 発生を予測するためには多くの地形・水文要素を具体的に知る必要があり, 多数の谷でこれらを求めるこ とはきわめて難しい。従って現段階では, それぞれの地方・地域での過去の土石流の発生例を集めて, 先 行雨量と現在の雨量強度の組み合わせで経験的に判断することが，もっとも現実的な方法である。

ただし先行雨量としては, 単に何時間前から積算するか, 先行時間が長くなるほどその重みを減じて加 算するかなどの方法が検討されている。
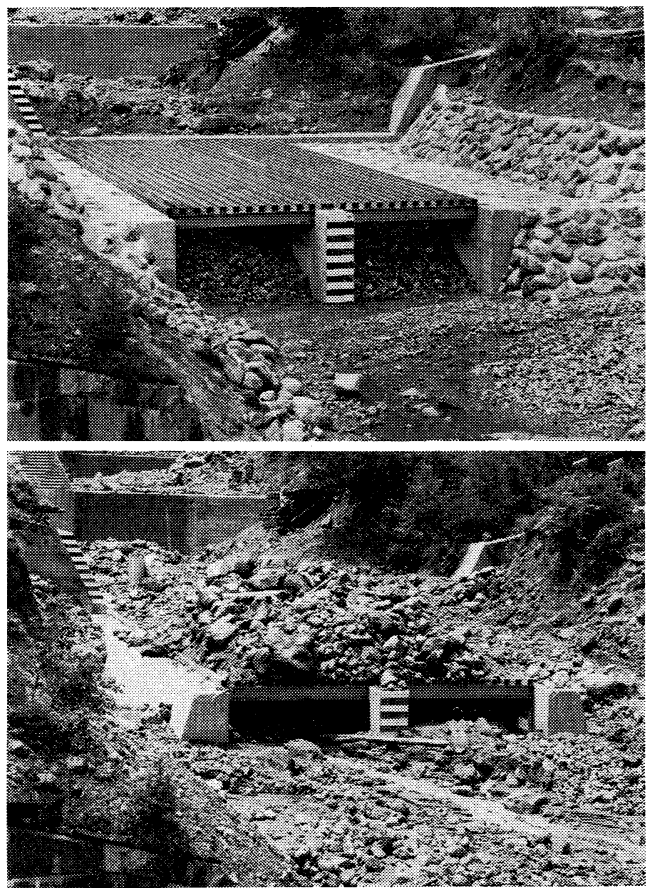

写真 2 底面スクリーン I（建設省松本砂防工 事事務所の設計・施工, 焼岳上々堀沢)

A. 土石流流下の前

B. 1985年 7 月 21 日の土石流流下の後
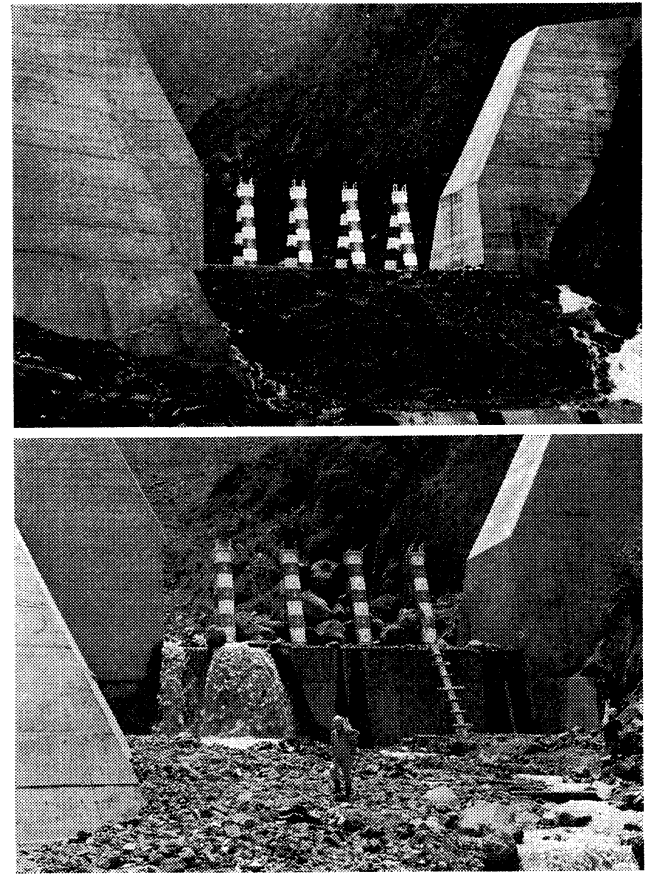

写真 3 鋼製パイプスリットダム（建設省松本 砂防工事事務所の設計・施工，浦川金 山沢）

A. 土石流流下の前

B. 土石流流下の後 
なお，計測システム開発の成果を生かして，上流に土石流が発生したことを確認して下流にいち早くそ の情報を伝える，土石流モニターシステムの開発も試みられている。

土石流発生の危険度の高い溪流については，最近の研究成果にもとづき，建設省の指導によって，その 指定・公表が進められている。しかし土石の汇濫域までを具体的に予測することには IV-3) で述べたよう に難しい問題が残されており，特定の地域を対象にした水理学的手法や確率論的手法に基つく危険域の予 測が研究的に試みられてはいるが，溪流現地への行政的適用・公表は行われていない。

土石流の運動そのものを制御しょうとする試みとしては，従来の，あるいは新型の，さまざまな砂防施 設の機能を科学的に評価することが行われている。特に現地計測システムを利用して実際の土石流が砂防 施設を通過する際の動態の変化を測定し，土石の捕捉や運動エネルギー減殺の効果を確かめようとする現 地実験が，主として建設省によって行われている。

最近は, 河川の流域全体での土砂の収支を配慮して, 通常の洪水時の流出土砂は通過させ，異常な土石 流発生時に直下流化被害をもたらす大きな岩塊群のみを捕捉しようとする新しい型の砂防施設の開発が行 われている。写真 2,3 はその一例を示すもので，隙間を持つ構造物によって，大きな岩塊の集団のみを 捕捉したり，水や細粒土砂と岩塊群を分離したりする方策がとられている。このような新施設の開発に際 しては, 土石流の物理的特性にもとづいた計画が必要であり, そのための基礎的な模型実験が大学や建設 省土木研究所などで行われている。

\section{謝辞}

本稿をまとめるに際して，防災研究所、諏訪 浩氏に多くの資料・写真をご提供をいただいた。ま た建設省松本砂防工事事務所には，共同研究の成果の利用，および最新の砂防施設に関する資料の提 供について特別のご協力をいただいた。ここに記して謝意を表する。

\section{引用文献}

芦田和男・江頭進治・神矢 弘・佐々木浩 (1985)：斜面に招ける土塊の抵抗則と移動速度. 京大防 災研年報，No. 28，B-2，297-307.

BAGNOLD, R. A. (1954) : Experiments on a gravity-free dispersion of large solid spheres in a Newtonian fluid under shear. Proc. Roy. Soc. London, A255, 49-63.

OKuda S., Suwa, H., OKunishi, K., Yokoyama, K. and NAKano, M. (1980) : Observations on the motion of a debrids flow and its geomorphological effects. Zeits. Geomorph. N. F. Suppl.-Bd. 35, 142-163.

奥田節夫・諏訪 浩 (1984)：扇状地に㧍ける 流出土砂の堆積の観測事例. 芦田和男編「扇状地の土 砂災害」古今書院，第二章，45-79.

奥田節夫（1986）：斜面崩壊にともなら物質の移動過程．地質学論集，第28号，97-106.

SASSA, K., KAIBORI, M. and KiterA, N. (1985): Liquefaction and undrained shear of torrent deposits as the cause of debris flows. Proc. of Int. Symp. on Erosion, Debris Flow and Disaster Prevention, 1985, Tsukuba, Japan, 231-236.

諏訪 浩 - 奥田節夫 一小川恒一 (1984)：土石流化抢ける粒度偏析過程（その1). 京大防災研年報,

No. 27, B-1, 409-423.

諏訪 浩・奥田節夫（1986）：土石流に㧍ける粒度偏析過程（その2)。京大防災研年報，No. 29，B$1,391-408$.

Suwa, H. and Okuda, S. (1986): Measurement of Debris Flows in Japan. Proc. IVth Int. Conf. and Field Workshop on Landslides, 1985, Tokyo, 391-400.

Suwa, H. and OKudA, S. (1987) : Seasonal Variation of Erosional Processes in The Kamikamihori Valley of Mt. Yakedake, Northern Japan Alps. CATENA, COMTAG, Symp. Vol. II, in press.

高橋 保 (1983)：土石流. 芦田・高橋・道上 共著「河川の土砂災害と対策」森北出版, 第 3 章, 73-89.

高橋 保 (1984)：土石流の流れ学。ながれ (日本流体力学会誌), Vol. 3, No. 4, 307-317.

武居有恒（1984）：土砂災害の危険範囲予測. 芦田和男編「扇状地の土砂災害」古今書院，第 5 章, 155-191. 